\title{
Persepsi Guru IPA SMP/MTs terhadap Praktikum IPA Selama Pandemi COVID-19
}

\author{
${ }^{1}$ Laila Khusnah \\ ${ }^{1}$ Prodi Pendidikan Tadris IPA, FTIK, Institut Agama Islam Negeri Jember \\ Email Korespondensi: lailakhusnah18@gmail.com
}

\author{
Article Info \\ Article History \\ Received: \\ Revised: \\ Published: \\ Keywords \\ Perception, \\ practicum, the COI \\ Pandemic \\ science
}

\begin{abstract}
The Corona Virus Disease 2019 (COVID-19) pandemic has shifted the faceto-face learning process in schools to an online learning process. This research aims to determine the perception of science teachers at SMP / MTs in Jember district on science practicum during the COVID-19 pandemic. Data was collected by distributing questionnaires in the form of google form through WhatsApp (WA) media to 24 SMP / MTs science teachers spread across Jember district by cluster sampling method from April to May 2020. The data obtained were analyzed using Microsoft Excel 2007. The survey results showed that $29 \%$ of teachers stated that they were ready to carry out practicum online, $38 \%$ stated that they were not ready and 33\% stated that they were not ready to carry out practicum online. This level of readiness affects the implementation of practicum activities. The survey results showed that the teachers who stated that practicum could be implemented were 33\%, the remaining $67 \%$ said that online practicum could not be implemented. This phenomenon occurs because there are constraints, both constraints originating from the teacher himself or obstacles originating from students and parents of students.
\end{abstract}

\section{Abstrak}

Pandemi Corona Virus Disease 2019 (COVID-19) menyebabkan proses pembelajaran tatap muka di sekolah dialihkan menjadi proses pembelajaran secara daring. Penelitian ini bertujuan untuk mengetahui persepsi guru IPA SMP/MTs yang ada di kabupaten Jember terhadap praktikum IPA selama pandemi COVID-19. Pengambilan data dilakukan dengan menyebar angket berupa google form melalui media WhatsApp (WA) kepada 24 guru IPA SMP/MTs yang tersebar di kabupaten Jemberdengan metode cluster samplingmulai bulan April sampai Mei tahun 2020. Data yang diperoleh dianalisis dengan menggunakan mocrosoft excel 2007. Hasil survey menunjukkan bahwa 29\% guru menyatakan siap melaksanakan praktikum secara daring, 38\% menyatakan kurang siap dan 33\% menyatakan tidak siap melaksanakan praktikum secara daring. Tingkat kesiapan tersebut berpengaruh terhadap keterlaksanaan kegiatan praktikum. Hasil survey menunjukkan bahwa guru yang menyatakan praktikum secara dapat terlaksana sebesar $33 \%$, selebihnya $67 \%$ menyatakan praktikum secara daring tidak dapat dilaksanakan. Fenomena tersebut terjadi karena terdapat kendala-kendala baik kendala yang berasal dari guru sendiri ataupun kendala yang berasal dari siswa dan orangtua siswa.

Sitasi: Khusnah, Laila. (2020). Persepsi Guru IPA SMP/MTs terhadap Praktikum IPA Selama Pandemi COVID-19. Science Education and Aplication Journal. 2(2). 112-118

\section{PENDAHULUAN (12pt)}

Pandemi Corona Virus Disease 2019(COVID-19) berpengaruh terhadap berbagai aspek kehidupan, salah satunya bidang pendidikan. Adanya pandemi tersebut menyebabkan pemerintah melalui menteri pendidikan dan kebudayaan, mengeluarkan Surat Edaran (SE) Nomor 4 tahun 2020 tentang pelaksanaan kebijakan pendidikan dalam masa darurat penyebaran COVID-19. Didalam SE disebutkan bahwa untuk menekan penyebaran COVID- 
19 kegiatan belajar yang biasanya dilaksanakan di sekolah, dialihkan dengan belajar jarak jauh dari rumah secara daring.SE tersebut berlaku untuk semua jenjang pendidikan dan semua sekolah di seluruh Indonesia, tak terkecuali di Kabupaten Jember Jawa Timur.

Pembelajaran jarak jauh secara daring, dilaksanakan dengan memanfaatkan berbagai media online.Menurut LPMP Jawa Timur (2020) kemendikbud melakukan kerjasama dengan media online antara lain Google Indonesia, Kelas Pintar, Microsoft, Quipper, Ruang Guru, Sekolahmu, dan Zenius. Selain itu, guru juga dapat menggunakan WhatApp sebagai media pembelajaran secara online(Prajana, A., 2017). Pemilihan penggunaan media tersebut merupakan wewenang dari guru yang disesuaikan dengan kondisi masing-masing sekolah dengan mempertimbangkan kemampuan serta latar belakang siswa maupun orangtua. Selain itu, yang terpenting dalam pemilihan media pembelajaran adalah memperhatikan prinsipprinsip pemilihan dan penggunaan media antara lain pemilihan media harus sesuai dengan tujuan yang ingin dicapai, harus berdasarkan konsep yang jelas, harus sesuai dengan karakteristik dan gaya belajar siswa, dan sesuai dengan kondisi lingkungan, fasilitas serta waktu yang tersedia untuk kebutuhan pembelajaran (Sanjaya, W. 2012).

Penggunaan berbagai platform media belajar online menunjukkan bahwa selama pandemi COVID-19 tidak lagi ada pertemuan tatap muka sebagaimana pembelajaran di sekolah. Guru tidak bisa melihat secara langsung proses belajar siswa secara detail, komunikasi dua arah sangat terbatas, perubahan atas sikap dan perilaku dari siswapun sulit untuk diamati. Selain itu, guru juga tidak bisa memberikan contoh perilaku secara langsung sebagai bentuk pendidikan pada siswa. Beberapa hal tersebut menyebabkan guru kesulitan dalam menumbuhkan dan menilai aspek afektifserta aspek psikomotor siswa. Padahal kedua aspek tersebut merupakan sasaran pembelajaran yang harus dicapai selain aspek kognitif (Permendikbud No. 65, 2013).

Mata pelajaran IPA merupakan mata pelajaran yang memiliki karakteristik antara lain IPA merupakan kumpulan pengetahuan berupa fakta, konsep dan ide yang merupakan produk ilmiah, dan diperoleh melalui proses ilmiah yang didalamnya didukung oleh sikap ilmiah (Ali, et al., 2013). Karakteristik mata pelajaran IPA tersebut berpengaruh terhadap proses pembelajaran IPA di sekolah. Menurut Khamidah, N dan Aprilia, N (2014), metode pembelajaran yang palingtepat untuk pembelajaran IPA adalah metode eksperimen/praktikum, karena dapat meningkatkan keterampilan siswa dalam melakukan pengamatan, mengoperasikan alat-alat, serta mengembangkan rasa ingin tahu, aktif, kreatif, inovatif, dan menumbuhkan kejujuran ilmiah. Untuk melaksanakan proses pembelajaran yang demikian perlu pendampingan dari guru secara langsung.

Ketika pembelajaran di sekolah, khususnya pembelajaran IPA SMP/MTs di Kabupaten Jember, dilaksanakan secara daring maka muncul dugaan bahwa kegiatan praktikum dalam pembelajaran IPA tidak dapat berjalan secara maksimal sebagaimana pembelajaran secara tatap muka. Olehkarena itu, peneliti melakukan survey untuk mengetahui pelaksanaan kegiatan praktikum IPA secara daring selama masa pandemi COVID-19 dan kendala-kendala yang dihadapi. Informasi yang diperoleh tersebut akan digunakan untuk memperbaiki proses pelaksanaan praktikum IPA secara daring pada semester berikutnya.

\section{METODE}

Penelitian ini menggunakan pendekatan penelitian kualitatif yaitu pendekatan pada deskripsi atas fenomena yang diteliti. Adapun jenis penelitian yang digunakan adalah penelitian deskriptif, dimana peneliti menggali lebih dalam mengenai persepsi guru terhadap praktikum IPA selama masa pandemi COVID-19.

Populasi yang digunakan adalah sekolah SMP/MTs yang ada di Kabupaten Jember, baik negeri maupun swasta.Sampel yang diambil adalah sebanyak 24 sekolah dengan metode 
cluster sampling. Adapun teknik pengambilan data yaitu dengan menyebarkan angket berupa google form melalui media WhatsApp mulai bulan April sampai Mei 2020.

\section{HASIL DAN PEMBAHASAN}

\section{Persepsi Guru Terhadap Kesiapan dalam Melaksanakan Praktikum Secara Daring}

Praktikum merupakan metode pembelajaran yang dapat digunakan untuk membuktikan suatu teori. Menurut Sapriati (2014), metode praktikummerupakan metode yang seringkali digunakan dalam mempelajari Ilmu Pengetahuan Alam dan pelaksanaannya tidak selalu harus didalam labolatorium tetapi dapat juga dilakukan di alam sekitar. Ada beberapa alasan pentingnya pelaksanaan praktikum IPA antara lain: dapat membangkitkan motivasi belajar IPA, mengembangkan keterampilan dasar eksperimen, menjadi wahana belajar pendekatan ilmiah, dan menunjang materi pelajaran (Rustaman, 2003).

Dengan adanya SE Nomor 4 tahun 2020 yang dikeluarkan oleh kemendikbud, maka pembelajaran yang ada di semua sekolah dilaksanakan secara daring. Di Jawa Timur tak terkecuali Kabupaten Jember, pembelajaran daring dimulai tanggal 16 Maret 2020. Pembelajaran daring ini terjadi serentak dan serba mendadak, karena terjadi pada hampir pertengahan semester. Semua guru harus segera menyesuaikan dengan kondisi tersebut dan pembelajaran harus tetap berlangsung dengan merubah semua perencanaan yang telah dirancang sebelumnya. Ketika dalam perencanaan sebelumnya tidak ada pertemuan yang bersifat online, maka saat itu guru harus segera mengambil tindakan untuk melaksanakan pembelajaran secara online. Hal ini juga terjadi pada guru mata pelajaran IPA yang sebagian besar dalam proses pembelajaran biasanya menggunakan metode praktikum dengan tatap muka, diganti dengan pembelajaran secara daring.

Berdasarkan hasil survey terkait kesiapan dalam melaksanakan praktikum secara daring, dapat diketahui bahwa 29\% guru menyatakan siap melaksanakan praktikum secara daring. Sementara itu, 38\% menyatakan kurang siap dan 33\% menyatakan tidak siap melaksanakan praktikum secara daring (Gambar 1).Guru menyatakan siap melaksanakan praktikum dikarenakan sebagian besar siswa memiliki sarana untuk belajar secara daring yang mendukung, seperti ketersediaan HP android para orangtua siswa dan sinyal yang kuat. Sedangkan mereka yang menyatakan kurang siap dan tidak siap melaksanakan praktikum secara daring dikarenakan sebagian besar siswa masih terkendala dengan sarana dan prasarana, keadaan sinyal dan suasana rumah yang kurang kondusif. Hal itu menunjukkan bahwa pada awal pemberlakuan pembelajaran daring pada masa pandemi COVID-19, SMP/MTs yang ada di Kabupaten Jember belum siap melaksanaan praktikum IPA.

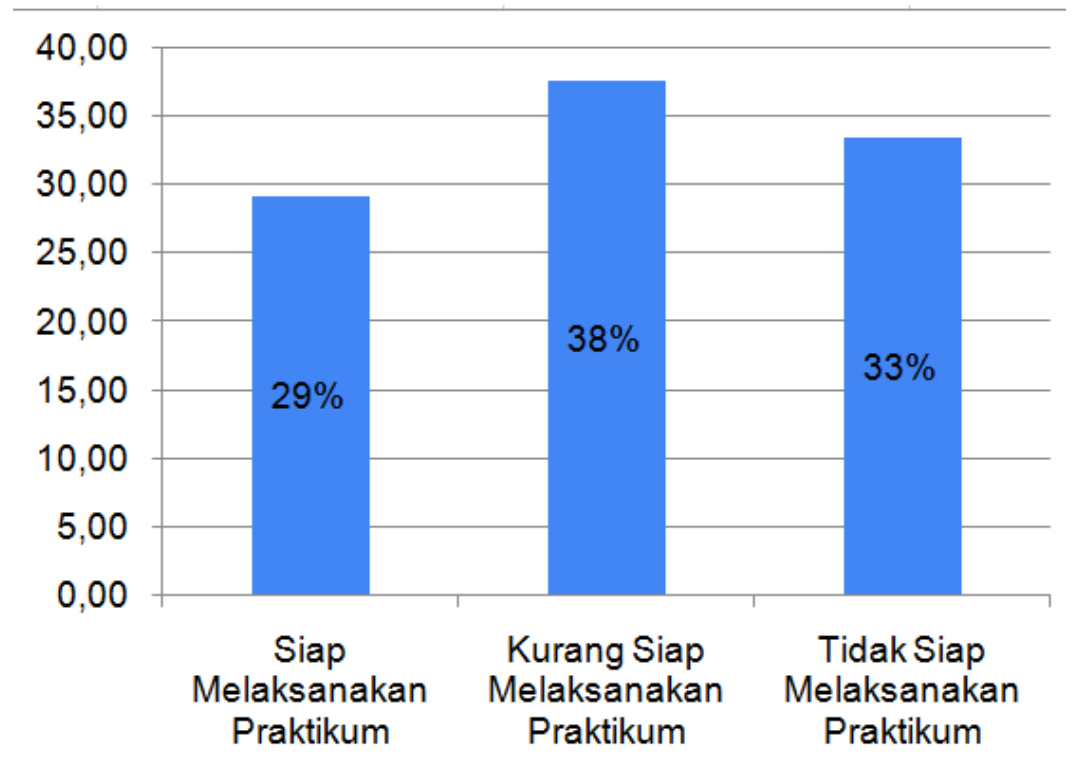


Gambar 1. Kesiapan dalam Melaksanakan Praktikum Selama Pandemi COVID-19

\section{Persepsi Guru Terhadap Keterlaksanaan Praktikum Secara Daring}

Praktikum dapat terlaksana dengan baik jika guru dan siswa telah dapat mempersiapkan diri dengan baik. Berdasarkan hasil survey, dapat diketahui bahwa guru yang menyatakan kegiatan praktikum secara daring dapat terlaksana adalah sebesar 33\%. Sedangkan $67 \%$ menyatakan bahwa kegiatan praktikum secara daring tidak dapat terlaksana (Gambar 2).Sebagian besar sekolah yang menyatakan siap melaksanakan praktikum secara daring adalah sekolah yang siswanya memiliki sarana prasarana berupa HP android. Kesiapan siswa tersebut dapat mendukung terhadap keterlaksanaan praktikum, seperti yang diungkapkan oleh Hasruddin \& Rezeqi (2012) bahwa pelaksanaan praktikum dapat dilakukan salah satunya karena adanya kesiapan dari siswa.

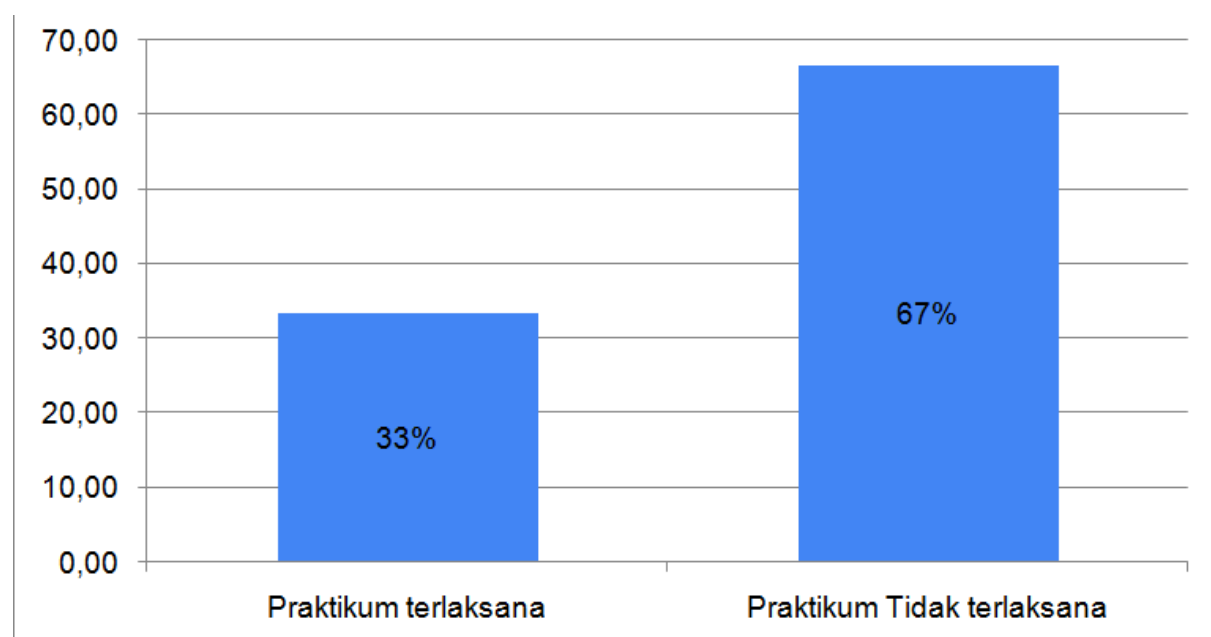

Gambar 2. Keterlaksanaan Praktikum Selama Pandemi COVID-19

Pelaksanaan praktikum secara daring dilakukan melalui video dan zoom. Dimana guru memberikan petunjuk langkah-langkah serta alat bahan dalam praktikum melalui dokumen atau video pada WA, google classroom atau melalui e-learning madrasah.Selanjutnya siswa melaksanakan praktikum dan kegiatan tersebut divideo kemudian video dikirimkan kepada guru. Sedangkan pelaksanaan praktikum yang dilakukan melalui zoom, guru sudah memberikan informasi terkait alat dan bahan yang harus dipersiapkan beserta langkahlangkah kerjanya sebelum hari pelaksanaan. Kemudian pada hari yang ditentukan, semua siswa telah siap melakukan praktikum bersama-sama dan guru dapat mengarahkan serta mengamati secara langsung apa yang dilakukan oleh siswa saat itu. Selain itu siswa juga bisa langsung menanyakan ketika ada langkah kerja yang belum dipahami. Hal ini menunjukkan bahwa praktikum secara daring dapat dilaksanakan dengan baik, sebagaimana hasil penelitian Nazila, Nervita dan Boni (2017) yang menyatakan bahwa pelaksanaan praktikum berjalan dengan baik jika pada tahap kerja,guru selalu mengontrol dan mengarahkan jalannya kegiatan praktikum, serta tanggap ketika siswa bertanya tentang kesulitan dalam melaksanakan proses praktikum. Namun, praktikum secara daring ini hanya dilaksanakan pada materi yang alat dan bahannya dapat diperoleh dengan mudah di rumah.

Berdasarkan gambar 2, sebagian besar guru menyatakan praktikum IPA selama masa pandemi COVID-19 tidak terlaksana. Hal ini dikarenakan instruksi pembelajaran daring datang secara tiba-tiba dan guru belum memiliki gambaran sama sekali bagaimana teknis pelaksanaan praktikum secara daring. Apalagi praktikum merupakan kegiatan yang 
membutuhkan pendampingan secara langsung oleh guru, supaya data yang dihasilkan tepat dan valid. Selain itu, masih banyak siswa yang tidak memiliki HP android dan tempat tinggal yang jauh dari jaringan internet. Padahal itu merupakan syarat utama dalam melaksanakan pembelajaran secara daring.Seperti yang diungkapkan oleh Gikas \& Grant(2013), pelaksanaan pembelajaran daring membutuhkan dukungan perangkat-perangkat mobile seperti smartphone/HP android, laptop, komputer, tablet dan iphone.

\section{Persepsi Guru Terhadap Hambatan dalam Melaksanakan Praktikum Secara Daring}

Berdasarkan hasil survey dapat diketahui bahwa praktikum IPA SMP/MTs secara daringmenglami banyak hambatan. Hambatan tersebut tidak hanya datang dari guru, namun juga dari siswa. Sebagian besar guru mengakui bahwa mereka kesulitan untuk merancang pelaksanaan praktikum secara daring, karena keterbatasan pengetahuan dan keterampilan dalam mengunakan teknologi. Hal ini sejalan dengan penelitian Dursun, T. etal (2013) menyatakan bahwa pendidikan saat ini dihadapkan pada banyak masalah, beberapa diantaranya ketertinggalan dari perkembangan dan teknologi, serta tenaga pendidik yang tidak memiliki keterampilan dan kualitas. Kedua, kurangnya ketersediaan sarana prasarana terkait paket data. Ketiga, keberadaanjaringan yang sangat terbatas bagi mereka yang tinggal di pedesaan atau wilayah pegunungan.Koneksi jaringan internet yang demikian dapat menghambat keberhasilan proses pembelajaran (Nurmukhametov,N.et al., 2015)

Selain hambatan-hambatan yang dialami sendiri oleh guru, mereka juga mengungkapkan adanya hambatan-hambatan yang berasal dari siswa. Diantaranya pertama, tidak semua alat bahan praktikum tersedia di rumah. Ketika alat dan bahan praktikum tidak dapat ditemukan secara lengkap, maka praktikum tidak akan berjalan secara maksimal. Kedua, latar belakang pendidikan dan ekonomi orantua siswa tidak sama. Kegiatan praktikum membutuhkan bimbingan dan dampingan, bagi orangtua yang memiliki latar belakang pendidikan rendah maka akan kesulitan untuk mengikuti pelajaran sekolah anaknya atau bahkan tidak nyambung sama sekali. Padahal keberhasilan akademik anak sangat ditentukan oleh keterlibatan orangtua dalam membimbing dan mendampingi anaknya belajar. Seperti penelitian yang dilakukan oleh Ishartiwi dan Raharja, S (2011) pada sekolah jenjang SMP di kabupaten Bantul, menyatakan bahwa keterlibatan orangtua secara nyata dalam proses pembelajaran anak dapat mempengaruhi terhadap hasil belajar akademik. Selain itu, masih banyak orangtua yang tergolong memiliki tingkat perekonomian sedang dan dibawah rata-rata. Sehingga kondisi yang demikian kurang mendukung terhadap ketersediaan HP android dan juga ketersediaan paket data siswa. Faktor ketiga, sebagian besar siswa juga berada pada wilayah pedesaan dan pegunungan yang sulit dijangkau oleh jaringan internet.Penggunaan media internet memiliki kendala yang cukup besar, koneksi jaringan dan kesalahan teknis seperti server down and error dapat menghambat keberhasilan proses pembelajaran (Nurmukhametov,N.et al., 2015).

\section{KESIMPULAN}

Berdasarkan hasil pemaparan mengenai persepsi guru IPA SMP/MTs di Kabupaten Jember terhadap Praktikum IPA selama pandemi COVID-19 dapat disimpulkan bahwa sebagian besar guru menyatakan praktikum IPA secara daring belum siap dilaksanakan dan $29 \%$ guru menyatakan siap melaksanakan praktikum secara daring. Sehingga hanya sebagian kecil saja (33\%) yang melaksanakan praktikum secara daring. Hal tersebut terjadi karena banyak kendala-kendala yang dialami baik dari pihak guru maupun siswa. Diantaranya guru kesulitan merancang pelaksanaan praktikum secara daring,keterbatasan pengetahuan dan keterampilan teknologi, keterbatasan alat bahan praktikum di rumah, tidak adanya pendampingan dari guru secara langsung serta keterbatasan perekonomian dan rendahnya pendidikan orangtua siswa. 


\section{SARAN}

Adanya berbagai kendala yang dihadapi oleh guru dalam pelaksanaan praktikum secara daring maka diperlukan antara lain pertama, adanya pelatihan atau work shop mengenai pembuatan buku pedoman praktikum mandiri kepada siswa, game praktikum virtual berbasis konten kurikulum, dan aplikasi praktikum virtual lainnya. Kedua, pemerintah perlu memperkuat jaringan internet terutama di pelosok desa dan wilayah pegunungan serta bantuan kuota data bagi siswa dan guru di sekolah.

\section{UCAPAN TERIMA KASIH}

Kami sampaikan terimakasih yang sebesar-besarnya kepada semua Bapak dan Ibu guru SMP/MTs di Kabupaten Jember yang telah berkenan meluangkan waktu untuk mengisi angket melalui google form dan mengungkapkan kendala-kendala yang terjadi di lapangan selama pelaksanaan praktikum secara daring pada masa pandemi COVID-19.

\section{DAFTAR PUSTAKA}

Ali, L.U., Suastra, I.W. \& Sudiatmika, A.A.I.A.R. (2013). Pengelolaan Pembelajaran IPA ditijau dari Hakikat Sains pada SMP di Kabupaten Lombok Timur. e-Journal Program Pascasarjana Universitas Pendidikan Ganesha Program Studi IPA, 3. (Online),(http://pasca.undiksha.ac.id/ejournal/index.php/jurnal_ipa/article/download/750/536)

Dursun, T., Oskaybas, K \& Gokmen, C. (2013). The Quality Of Service Of The Distance Education. Procedia - Social and Behavioral Sciences, 103, 11331151.(Online),https://doi.org/10.1016/j.sbspro.2013.10.441

Gikas and Grant. (2013). Mobile computing devices in higher education: Student perspectives on learning with cellphones, smartphones \& social media. TheInternet and Higher Education, Vol.19, October 2013, Pages 18-26. (Online),https://doi.org/10.1016/j.iheduc.2013.06.002

Hasruddin dan Rezeqi S 2012. Analisis Pelaksanaan Praktikum dan Permasalahannya si SMA Negeri se-Kabupaten Karo. Jurnal Tabularasa PPS UNIMED, 9 (1), 17-32. (Online). (http://digilib.unimed.ac.id/1402/1/Fulltext.pdf)

Ishartiwi dan Raharja, S. (2011). Peran Keluarga dalam Pendidikan Siswa SMP di Kabupaten Bantul. Laporan Penelitian. Yogyakarta: Pusat Penelitian Pendidikan Dasar dan Menengah, Lembaga Penelitian UNY. (Online),http://staffnew.uny.ac.id/upload/132169259/penelitian/laporan-peran-ortu11.pdf

Khamidah,N dan Aprilia, N. (2014). Evaluasi Program Pelaksanaan Praktikum Biologi Kelas XI SMA Se-Kecamatan Umbulharjo Yogyakarta Semester II Tahun Ajaran 2013/2014. $\begin{array}{lllll}\text { JUPEMASI-PBIO, } & 1 & (1), & 5-8 . & \text { ISSN: }\end{array}$ (Online),http://jupemasipbio.uad.ac.id/wp-content/uploads/2014/11/2.NP_11A08023_NUR-KHAMIDA.pdf

LPMP Jatim. (2020). What App Paling diminati untuk Pembelajaran Online. 03 April 2020. (Online),https://lpmpjatim.kemdikbud.go.id/site/detailpost/whatsapp-paling-diminatiuntuk-pembelajaran-online

Nazila, Nervita \& Boni. (2017). Analisis Pelaksanaan Praktikum Pada Pembelajaran Biologi Kelas X MAN Tanjung Pinang Tahun Ajaran 2016/2017. Jurnal Umroh. 1(1): 2541.(Online),http://repository.umrah.ac.id/739/1/artike1\%20Ejurnal\%20Nurul\%20Nazila.pdf

Nurmukhametov, N., Temirova, A., \& Bekzhanova, T. (2015). The Problems of Development of Distance Education in Kazakhstan. Procedia - Social and Behavioral Sciences, 182, 15-19.(Online),https://doi.org/10.1016/j.sbspro.2015.04.729 
Peraturan Menteri Pendidikan dan Kebudayaan No. 65 Tahun 2013 Tentang Standar Proses Pendidikan Dasar dan Menengah. Pendidikan Biologi Fakultas Keguruan dan Ilmu Pendidikan Universitas Sebelas Maret. (Online), (http://biologi.fkip.uns.ac.id/wpcontent/uploads /2013/08/PDK-2013-65-Standar-Proses.pdf).

Prajana, A. (2017). Pemanfaatan Aplikasi WhatsApp dalam Media Pembelajaran di UIN Raniry Banda Aceh. Jurnal Pendidikan Teknologi Informasi. 1(2), 122133.(Online),jurnal.ar-raniry.ac.id > cyberspace > article > download

Rustaman, N.2003. Strategi Belajar MengajarBiologi.Bandung:Universitas Pendidikan Indonesia.

Sanjaya, W. (2012). Perencanaan dan Desain Sistem Pembelajaran. Jakarta: Kencana Prenada Media Group.

Sapriati, A. dkk. (2014). Pembelajaran IPA di SD. Jakarta: Universitas Terbuka. 